\title{
CD2-1, the C-Terminal Region of Flagellin, Modulates the Induction of Immune Responses in Rice
}

\author{
Yuya Katsuragi, Ryota Takai, Takehito Furukawa, Hiroyuki Hirai, Takumi Morimoto, Takara Katayama, \\ Takahiko Murakami, and Fang-Sik Che
}

Graduate School of Biosciences, Nagahama Institute of Bio-Science and Technology, 1266, Tamura, Nagahama, Shiga

526-0829, Japan

Submitted 22 November 2014. Accepted 18 January 2015.

\begin{abstract}
Flagellin from the rice avirulent $N 1141$ strain of Acidovorax avenae functions as a pathogen-associated molecular pattern (PAMP) and induces PAMP-triggered immunity (PTI) in rice. To study the recognition mechanism of flagellin in rice, we attempted to define one or more regions of the flagellin protein required to activate the PTI response. Based on domain classification, we produced four fragments of N1141 flagellin: N-terminal D0, D1. and D2 domains (ND0-2), N-terminal D2, D3, and C-terminal D2 domains (ND2-CD2), C-terminal D2, D1, and D0 domains (CD2-0), and C-terminal D2 and D1 domains (CD2-1). The C-terminal CD2-1 and CD2-0 fragments induced PTI responses in cultured rice cells. Synthetic flg22, which is sufficient to produce the flagellin response in Arabidopsis, and the $\mathrm{N}$-terminal flagellin fragments containing flg22 region elicited very weak immune responses in rice. OsFLS2, the rice ortholog of AtFLS2, which mediates flg22 recognition, was not involved in CD2-0 or CD2-1 recognition in rice. In addition, CD2-0 triggered resistance to coinfection with pathogenic bacteria. Taken together, these data suggest that rice mainly recognizes flagellin CD2-1 by a receptor distinct from OsFLS2 and that this epitope recognition leads to PTI responses.
\end{abstract}

In nature, plants are exposed to a variety of microorganisms, including potential pathogens. Nevertheless, disease development is the exception rather than the rule because of a phenomenon termed the plant immune response, which conveys protection against specific pathogen species. Plants have evolved a multilayered defense system that can be activated upon pathogen invasion (Jones and Dangl 2006). The first line of the active defense system relies upon the recognition of pathogen-associated molecular patterns (PAMPs) or microbe-associated molecular patterns (MAMPs) by pattern recognition receptors. The recognition of PAMPs or MAMPs causes PAMP-triggered immunity (PTI), which includes the generation of reactive oxygen species in the apoplast, mediated by the NADPH oxidase respiratory burst homolog, callose deposition, and global changes in expression of several immune-related genes containing WRKY transcription factors and pathogenesis-related genes (Boller and Felix 2009). The importance of PTI is highlighted by the enhanced susceptibility of plants bearing mutations in PTI recognition or signaling components to colonization by adapted or nonadapted bacteria. In

Corresponding author: F. S. Che; E-mail: k_sai@nagahama-i-bio.ac.jp

*The $\boldsymbol{e}$-Xtra for "electronic extra" and indicates that two supplementary figures are published online.

@ 2015 The American Phytopathological Society most cases, PTI partially prevents pathogens from infecting the plant. To overcome PTI, pathogens inject effector proteins into plant cells, which interfere with defense responses and suppress immunity. Some plants have evolved the ability to sense specific pathogen effectors by resistance proteins leading to effectortriggered immunity (ETI). Often ETI is quantitatively stronger than PTI and is accompanied by hypersensitive response, a form of programmed cell death.

PAMPs include characteristic structures from pathogens, such as $\beta$-glucan (Klarzynski et al. 2000), chitin (Kaku et al. 2006), ergosterol (Laquitaine et al. 2006), lipopolysaccharide (LPS) (Silipo et al. 2005), flagellin (Che et al. 2000; Felix et al. 1999), and the translation elongation factor EF-Tu (Kunze et al. 2004). Among these PAMPs, flagellin, the main component of the bacterial flagellum, has been the most extensively studied with respect to its PAMP recognition mechanism and downstream signaling events. The bacterial flagellum consists of a basal body that functions as a rotary motor, a hook apparatus, and filament that consists of thousands of flagellin monomers (Schuster and Khan 1994). Although flagellin monomers are sequentially secreted through the channel and polymerized to form the filament, some flagellins are mistakenly released by the bacterium as a result of leakages or spill over during flagellum construction (Komoriya et al. 1999). As such, flagellin is an ideal sentinel molecule for monitoring the presence of bacteria. Indeed, flagellin is also recognized by Drosophila spp. (Samakovlis et al. 1992) and mammals (Wyant et al. 1999). In Arabidopsis, a synthetic 22-amino acid peptide (flg22) comprising the most conserved region within the $\mathrm{N}$-terminal portion of flagellin is sufficient to produce a PTI response in tomato and a variety of species, including Arabidopsis thaliana (Felix et al. 1999). Recognition of this active domain depends upon FLS2 (flagellin sensing 2), a receptor-like kinase (RLK) composed of an extracellular leucine rich repeat (LRR) domain, a single membrane-spanning domain, and a cytoplasmic serine/threonine kinase domain (Gómez-Gómez and Boller 2000). FLS2 and flg22 physically interact, suggesting that FLS2 determines the specific recognition of flagellin.

Acidovorax avenae is a gram-negative phytopathogenic bacterium that causes brown stripe in infected susceptible plants. Collectively, A. avenae infects a wide range of monocotyledonous host plants, including rice, oats, Italian millet, and maize. However, individual strains of the pathogen infect only one or a few host species (Kadota et al. 1996). We previously reported that the rice-avirulent strain N1141 induced several immune responses in rice cells, while the rice-virulent strains H8301 and K1 did not (Che et al. 1999; Fujiwara et al. 2004; Iwano et al. 2002; Tanaka et al. 2001, 2003). To identify the specific recognition molecules related to the induction of 
these immune responses in cultured rice cells, a strain-specific antibody was raised against the avirulent strain and, then, incubated with the virulent strain. The specific antibody detected the flagellin protein, which is structurally different between virulent and avirulent strains of $A$. avenae (Che et al. 2000). Flagellin purified from the rice-avirulent strain N1141 specifically induced immune responses in rice, e.g., such as $\mathrm{H}_{2} \mathrm{O}_{2}$ generation and the expression of defense-related genes, whereas no immune responses were observed upon treatment with flagellin purified from H8301 or K1. Furthermore, we demonstrated that a flagellin-deficient N1141 mutant lost the ability to induce immune responses. These results suggest that flagellin purified from the avirulent strain of A. avenae functioned as a PAMP to specifically elicit the PTI system (Che et al. 2000).

Rice has the highly homologous receptor to Arabidopsis FLS2, termed OsFLS2. Because expression of OsFLS2 in the Arabidopsis fls 2 mutant conferred the flg 22 recognition ability, OsFLS2 effectively functions as a flg22 receptor. Furthermore, the OsFLS2-overexpressed transgenic rice line caused several immune responses by flg22 and flagellin treatment (Takai et al. 2008). However, very weak PTI induction was observed by flg22 treatment as compared with recombinant and native N1141 flagellins. The data indicated that OsFLS2 hardly functions as a flagellin receptor in rice, owing to there being low expression levels, and PTI responses in rice are mainly caused by the recognition of the flagellin domain, unlike the flg22. However, the main flagellin epitope recognized by rice and the details underlying the flagellin detection system in rice are not fully understood.

Here, we show that recombinant flagellin from A. avenae N1141 produced in an Escherichia coli expression system acted as a PAMP in rice and caused several PTI responses, including $\mathrm{H}_{2} \mathrm{O}_{2}$ generation, callose deposition, and the induction of several immune-related genes. A PTI induction experiment using several N1141 flagellin recombinant fragment peptides revealed that rice cells have a sensitive perception system that specifically recognizes CD2-1 fragments, composed of C-terminal D2 and D1 domains of N1141 flagellin, and that CD2-1 appears to be required for full PAMP activity of flagellin in rice. By contrast, a synthesized flg22 region from $A$. avenae N1141 did not induce remarkable PTI responses in rice, although the peptide was able to induce immune responses in Arabidopsis. We also demonstrated that recognition of CD2-1 by rice was not mediated by $O s F L S 2$, the rice ortholog of AtFLS2, which encodes the receptor for flg22 in Arabidopsis. Our results indicate the existence of a novel flagellin recognition system in rice.

\section{RESULTS}

\section{Recombinant N1141 flagellin induces several immune responses in rice.}

We previously reported that flagellin purified from the avirulent strain of $A$. avenae, N1141, induced PTI responses in cultured rice cells but that flagellin purified from the virulent K1 strain did not (Che et al. 2000; Tanaka et al. 2003). To clarify the mechanism of flagellin perception in rice, we first produced recombinant $\mathrm{N} 1141$ flagellin protein in an E. coli expression system and tested the ability of the flagellin protein to induce immune responses. The generation of reactive oxygen species is known as an early PTI reaction. Therefore, we first examined whether recombinant flagellin induced $\mathrm{H}_{2} \mathrm{O}_{2}$ generation in cultured rice cells. When recombinant N1141 flagellin was added to cultured rice cells, $\mathrm{H}_{2} \mathrm{O}_{2}$ was generated within $1 \mathrm{~h}$ posttreatment, and the rate of $\mathrm{H}_{2} \mathrm{O}_{2}$ generation gradually decreased for $3 \mathrm{~h}$ posttreatment (Fig. 1A). The same pattern of $\mathrm{H}_{2} \mathrm{O}_{2}$ generation was observed in cultured rice cells treated with flagellin protein purified from avirulent N1141 strain (Fig. 1A).
The maximal generation of $\mathrm{H}_{2} \mathrm{O}_{2}$ was observed with a dose of $1 \mu \mathrm{M}$ of recombinant $\mathrm{N} 1141$ flagellin or the purified native N1141 flagellin. The half-maximal effective concentrations were estimated at 63.3 and $26.3 \mathrm{nM}$ for the purified native and recombinant N1141 flagellin proteins.

The expression of OsWRKY70, which encodes a flagellininducible transcription factor (Takai et al. 2007), OsCht-I, which encodes chitinase (Tanaka et al. 2003), and PBZ1, which encodes a probenazole-inducible protein (Nakashita et al. 2001), were all increased in cells upon the addition of the purified native N1141 flagellin (Fujiwara et al. 2004). Therefore, a time course of gene expression activated by recombinant flagellin treatment was followed by quantitative reverse transcription-polymerase chain reaction (qRT-PCR) in cultured rice cells. OsWRKY70 transcripts were induced $1 \mathrm{~h}$ posttreatment with recombinant N1141 flagellin and were gradually reduced over $6 \mathrm{~h}$ (Fig. 1C). OsCht 1 and PBZl transcripts were observed $3 \mathrm{~h}$ posttreatment with both the recombinant and native N1141 flagellins, and their expression levels increased for up to $6 \mathrm{~h}$ posttreatment (Fig. 1D and E).

Callose deposition is another component of plant PTI responses (Luna et al. 2011). When cultured rice cells were treated with the recombinant and the native N1141 flagellins and were stained with aniline blue $16 \mathrm{~h}$ posttreatment to visualize callose, more abundant callose deposition was observed in the treated cells as compared with controls (Fig. 1F, G, and H). In total, these results suggested that both recombinant and native N1141 flagellin proteins act as PAMPs in rice cells.

\section{Contribution of flg22 to PTI responses induced by the N1141 flagellin in rice.}

In Arabidopsis, flg22, a 22-amino acid peptide comprising the most conserved N-terminal domain of flagellin, was identified as a recognition epitope. To explore the flagellin recognition epitope that is active in rice cells, flg22 and the flg22 region of $A$. avenae N1141 flagellin (flg22-avenae) were chemically synthesized and examined for their ability to induce $\mathrm{H}_{2} \mathrm{O}_{2}$ generation. When flg22 or flg22-avenae were added to cultured rice cells, weak induction of $\mathrm{H}_{2} \mathrm{O}_{2}$ generation was observed (Fig. 2A). Next, we examined whether the PTI-related genes $O s W R K Y 70$, Cht-1, and PBZ1 that were induced by N1141 flagellin were induced by flg 22 treatment in cultured rice cells, using qRT-PCR as a read out. No induction of these three genes was observed in flg22treated cultured rice cells (Fig. 2C, D, and E). These results indicate that rice PTI responses induced by N1141 flagellin are mainly caused by the recognition of the flagellin domain unlike the flg22.

To determine the contribution of flg22 to PTI responses induced by the flagellin domain unlike the flg22, the synergistic effect of flg22 was examined. Recombinant N1141 flagellin was added to cultured rice cells at several concentrations in the presence of $10 \mu \mathrm{M}$ flg22, and $\mathrm{H}_{2} \mathrm{O}_{2}$ generation was analyzed. The addition of flg 22 to cultured rice cells did not affect the ability of recombinant N1141 flagellins to induce the $\mathrm{H}_{2} \mathrm{O}_{2}$ (Fig. 2B), indicating that flg22 was neither antagonistic nor agonistic with respect to this N1141 flagellin activity.

We previously reported that $O s F L S 2$ shared homology with AtFLS2 (45\%), which encodes the receptor for flg22 in Arabidopsis. Complementation testing using an Arabidopsis fls 2 mutant revealed that OsFLS2 restored flg22-dependent plant immune responses in the $f l s 2$ mutant, suggesting that OsFLS2 may function as a receptor (Takai et al. 2008). To clarify the participation of OsFLS2 in PTI responses induced by N1141 flagellin in cultured rice cells, we assessed the induction of immune responses by N1141 flagellin in an OsFLS2-deficient (knocked-down) mutant. For these RNA interference (RNAi) 
experiments, a 325-bp region of $O s F L S 2$ cDNA that encodes the C-terminus was selected. This segment contained the $3^{\prime}$ untranslated region and the kinase region, which is necessary for the signal transduction activity of OsFLS2. Moreover, this region had no homology for any genes other than OsFLS2. We generated two lines of cultured rice cells carrying the $O s F L S 2$ RNAi construct (OsFLS2 RNAi-2 and OsFLS2 RNAi-3) and one control transformant carrying the empty vector. Quantification of OsFLS2 by qRT-PCR showed that $O s F L S 2$ RNAi-2 and RNAi-3 exhibited 10fold or greater reductions in $O S F L S 2$ levels as compared with the control line (Fig. 3A). The control line and the OsFLS2 RNAi-2 and RNAi-3 lines all demonstrated the same ability to generate $\mathrm{H}_{2} \mathrm{O}_{2}$ in response to treatment with $300 \mathrm{nM}$ of the native N1141 flagellin (Fig. 3B).

We previously reported that expression of $P A L$, which encodes the enzyme catalyzing the deamination of L-phenylalanine to transcinnamic acid, the first step in the biosynthesis of lignin monomers and certain classes of phytoalexins (Zhu et al. 1995), was induced $3 \mathrm{~h}$ posttreatment with the N1141 native flagellin, that $P A L$ levels increased $6 \mathrm{~h}$ postinoculation (Tanaka et al. 2003). When native N1141 flagellin was added to the control line and to the OsFLS2 RNAi-2 and RNAi-3 lines, the same levels of $P A L$ transcripts were observed in all three cell lines (Fig. 3C). Taken together, these results indicated that OsFLS2 was not involved in the recognition of the flagellin domain distinct from flg22 in rice cells.

\section{Identification of the PAMP epitope of N1141 flagellin in rice.}

Because PTI responses in rice were not induced by the flg 22 region of N1141 flagellin, we tried to define the exact epitope of N1141 flagellin in rice. The flagellin structure can be divided into four domains, D0, D1, D2, and D3, in order of their radial positions along the flagellar filament from inside to outside (Samatey et al. 2001; Yonekura et al. 2003). The N-terminus starts at D0; then, the protein goes through D1, D2, and D3, and then, comes back through D2 to D1. The C-terminal chain ends in D0. Based on this domain classification, we produced four fragments of N1141 flagellin as glutathione-S-transferase

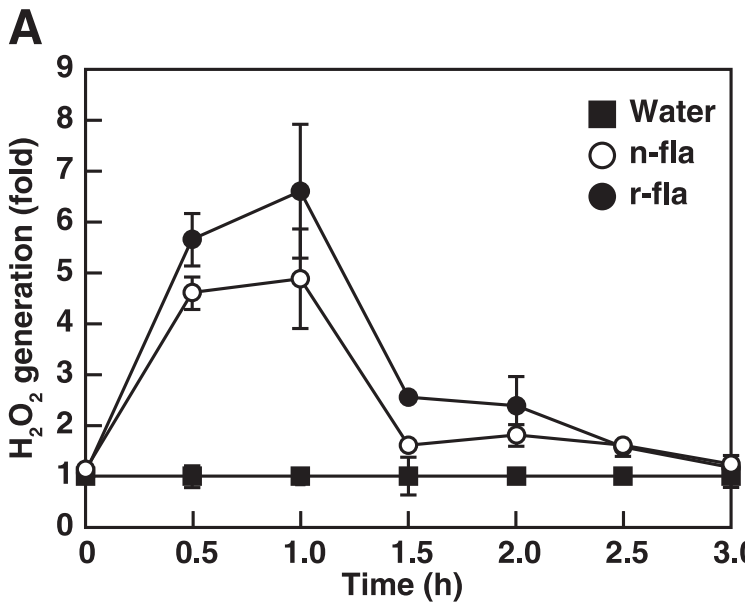

B

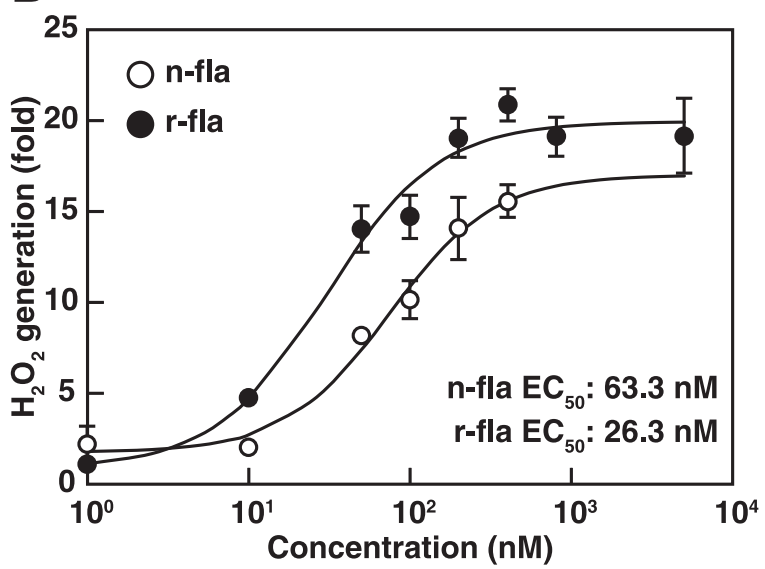

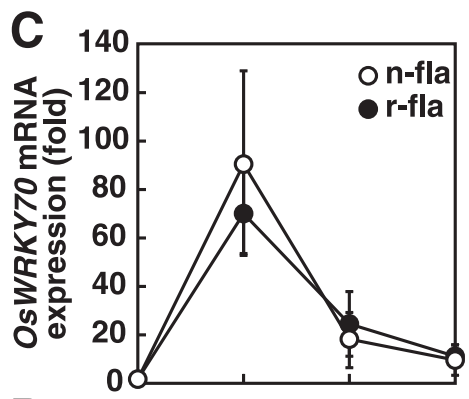

$F$
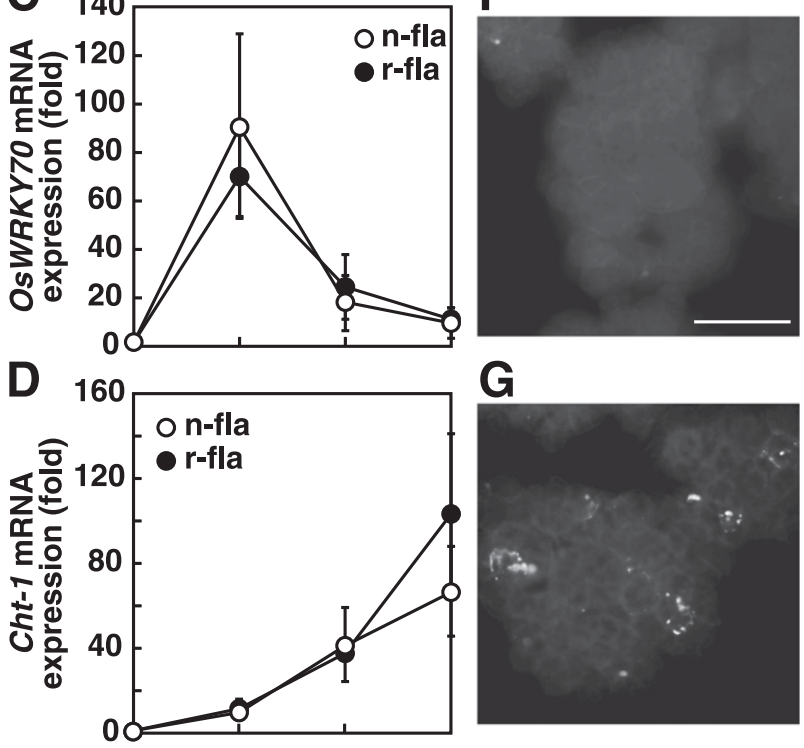

G
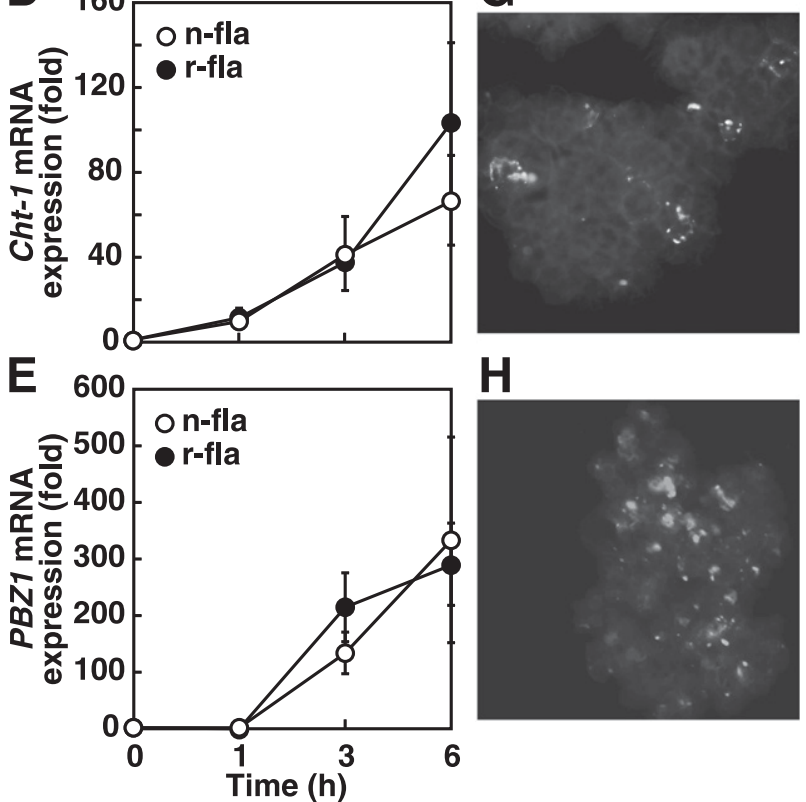

H

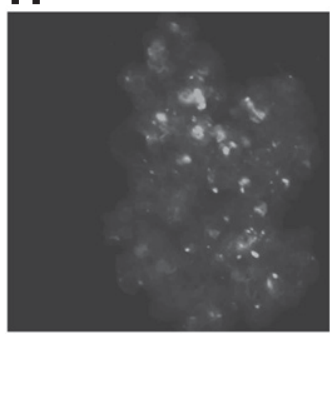

Fig. 1. Induction by native flagellin and recombinant flagellin in rice. A, Time course of $\mathrm{H}_{2} \mathrm{O}_{2}$ generation in cultured rice cells treated with 200 nM native N1141 flagellin (n-fla; open circles), recombinant N1141 flagellin (r-fla; solid circles), or water (solid squares). The $y$ axis represents fold change relative to the amount of $\mathrm{H}_{2} \mathrm{O}_{2}$ in water-treated cultured rice cells. Bars indicate the standard deviation of the mean of six experiments. B, Dose-dependent induction of $\mathrm{H}_{2} \mathrm{O}_{2}$ generation in cultured rice cells induced by native N1141 flagellin (n-fla; open circles) or recombinant N1141 flagellin (r-fla; solid circles). $\mathrm{H}_{2} \mathrm{O}_{2}$ generation was analyzed at $1 \mathrm{~h}$ posttreatment with 1, 10, 50, 100, 200, 400, 800, or 5,000 nM native or recombinant N1141 flagellins. The $y$ axis represents fold change relative to the amount of $\mathrm{H}_{2} \mathrm{O}_{2}$ in water-treated cultured rice cells. Bars indicate the standard deviation of the mean of six experiments. C, mRNA levels of $O s W R K Y 70, \mathbf{D}$, Cht -1 , or E, PBZ1 in cultured rice cells that were treated with $500 \mathrm{nM}$ native N1141 flagellin (n-fla; open circles) or recombinant N1141 flagellin (r-fla; solid circles). mRNA levels were calculated from the threshold point located in the log-linear range. The $y$ axis represents the fold change in mRNA levels relative to the levels in mock-treated cultured rice cells. Error bars indicate the standard deviation of three experiments. F, Callose deposition in cultured rice cells 16 h posttreatment with water, G, 200 nM native N1141 flagellin, or H, recombinant N1141 flagellin. 
(GST) fusion proteins in E. coli; N-terminal D0, D1, and D2 domains (ND0-2), N-terminal D2, D3, and C-terminal D2 domains (ND2-CD2), C-terminal D2, D1, and D0 domains (CD2-0), and C-terminal D2 and D1 domains (CD2-1). We removed the GST portion of each fusion protein using Prescission protease (Fig. 4A). Cultured rice cells treated with CD20 and CD2-1 protein domains produced higher levels of $\mathrm{H}_{2} \mathrm{O}_{2}$ $60 \mathrm{~min}$ posttreatment as compared with cells treated with
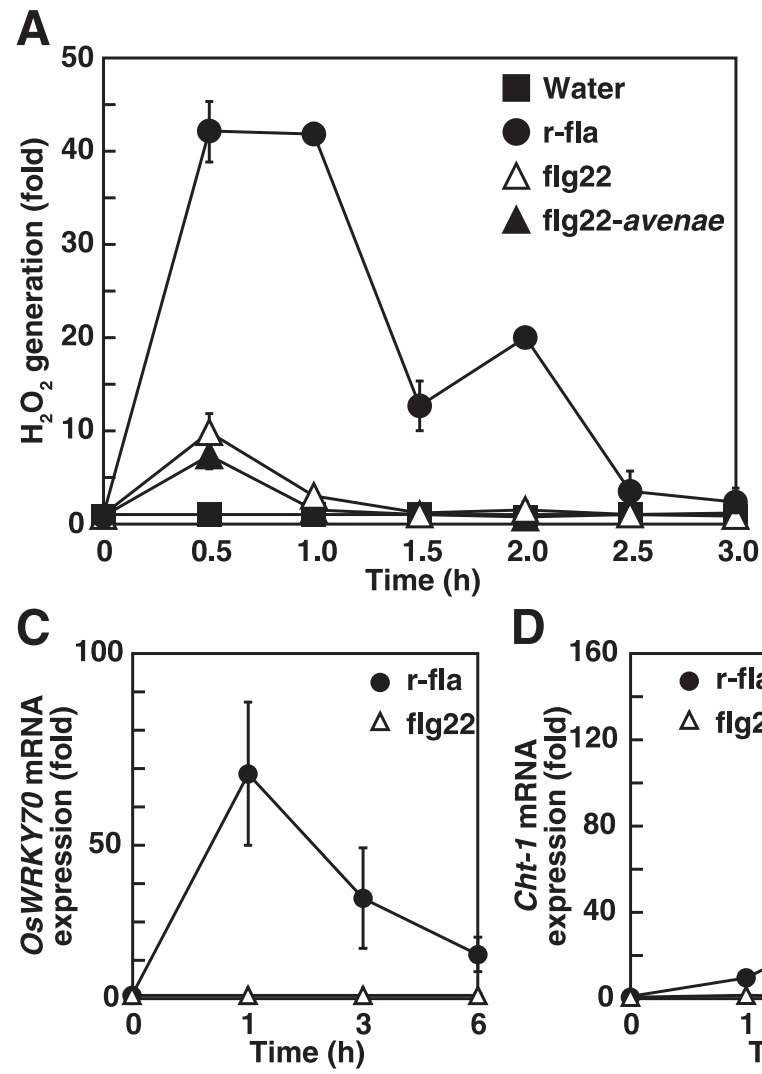

B

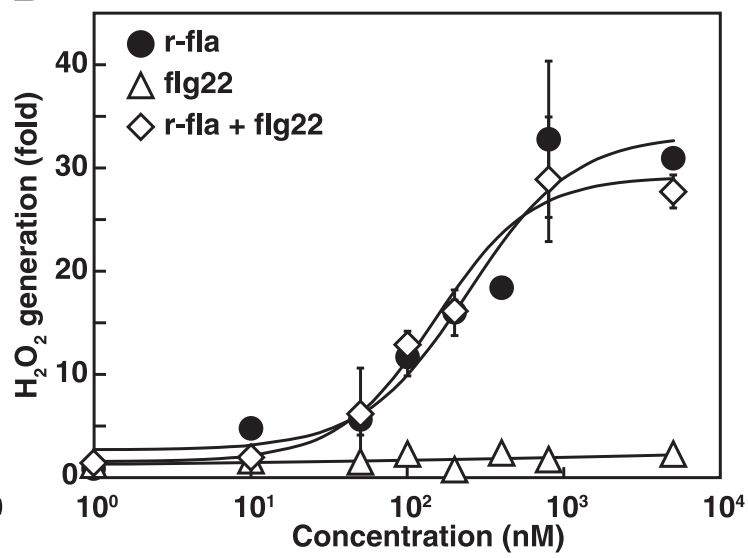

E
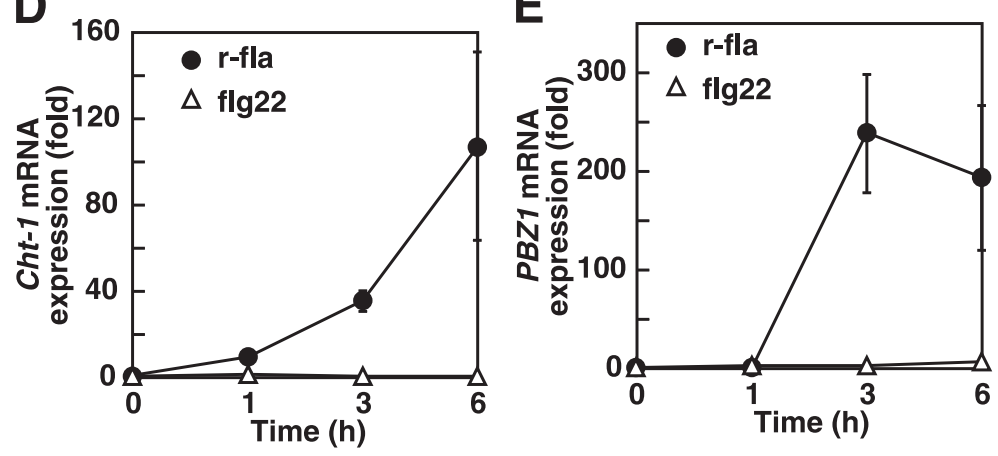

Fig. 2. Effect of flg22 on induction in cultured rice cells. A, Time course of $\mathrm{H}_{2} \mathrm{O}_{2}$ generation in cultured rice cells treated with $200 \mathrm{nM}$ recombinant $\mathrm{N} 1141$ flagellin ( $\mathrm{r}$-fla; solid circles), flg22 (open triangles), flg22-avenae (solid triangles), or water (solid squares). The $y$ axis represents fold change relative to the amount of $\mathrm{H}_{2} \mathrm{O}_{2}$ in water-treated cultured rice cells. Bars indicate the standard deviation of the mean of seven experiments. B, Dose-dependent induction of $\mathrm{H}_{2} \mathrm{O}_{2}$ generation in cultured rice cells induced by recombinant $\mathrm{N} 1141$ flagellin (r-fla; solid circles), flg22 (open triangles), or recombinant N1141 flagellin plus flg22 (open diamonds). The $y$ axis represents fold change relative to the amount of $\mathrm{H}_{2} \mathrm{O}_{2}$ in water-treated cultured rice cells. Bars indicate the standard deviation of the mean of three experiments. C, mRNA levels of $O s W R K Y 70, \mathbf{D}, C h t-1$, or $\mathbf{E}, P B Z 1$ in cultured rice cells that were treated with $500 \mathrm{nM}$ recombinant N1141 flagellin (r-fla; solid circles) or flg22 (open triangles). mRNA levels were calculated from the threshold point located in the log-linear range. The $y$ axis represents the fold change in mRNA levels relative to the levels in mock-treated cultured rice cells. Error bars indicate the standard deviation of three experiments.

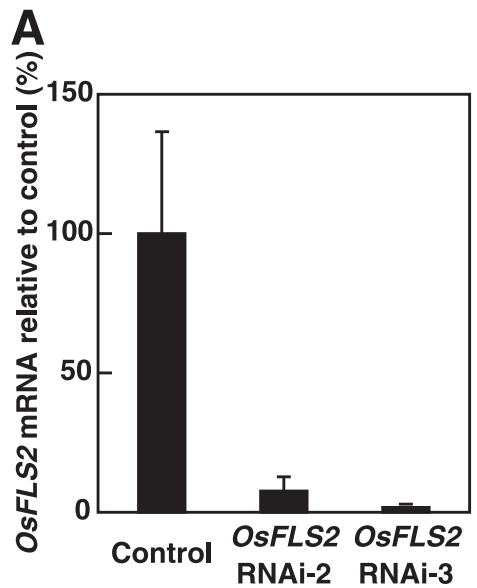

B

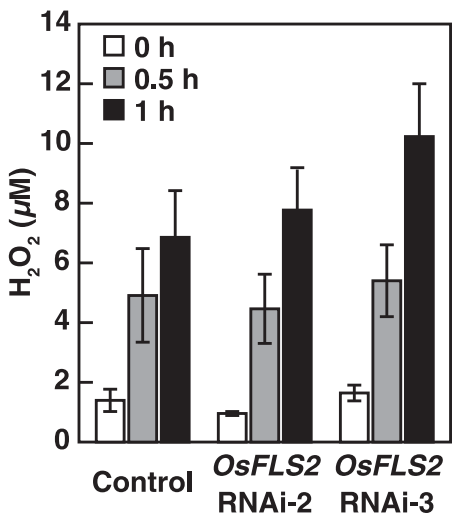

C

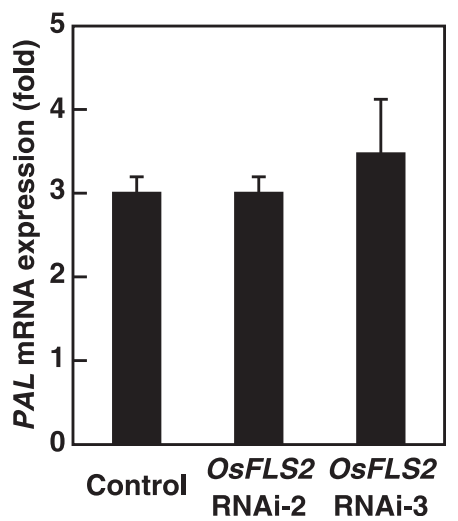

Fig. 3. Contribution of OsFLS2 to flagellin recognition in cultured rice cells. A, mRNA levels of $O s F L S 2$ in each $O s F L S 2$ RNAi line were analyzed by real time reverse transcription-polymerase chain reaction (RT-PCR). $\mathbf{B}, \mathrm{H}_{2} \mathrm{O}_{2}$ generation in each OsFLS2 RNAi line at 0, 0.5, and $1 \mathrm{~h}$ posttreatment with $300 \mathrm{nM}$ native N1141 flagellin. C, mRNA levels of PAL in each OsFLS2 RNAi line. mRNA levels were calculated from the threshold point located in the log-linear range of RT-PCR. The $y$ axis represents the fold change in mRNA levels relative to the levels in mock-treated cultured rice cells. Error bars indicate the standard deviation of three experiments. 
recombinant N1141 flagellin, whereas low-level induction of $\mathrm{H}_{2} \mathrm{O}_{2}$ generation was observed when cells were treated with ND0-2 or ND2-CD2 protein domains (Fig. 4B). To confirm the specific immune induction of CD2-0 and CD2-1 in rice cells, Arabidopsis suspension cells were also treated with ND0-2, ND2-CD2, CD2-0, and CD2-1, and $\mathrm{H}_{2} \mathrm{O}_{2}$ generation was measured. Treatment with neither CD2-0 nor CD2-1 induced $\mathrm{H}_{2} \mathrm{O}_{2}$ generation, whereas ND0-2, which included the flg22 region, caused strong induction of $\mathrm{H}_{2} \mathrm{O}_{2}$ generation in Arabidopsis cells (Fig. 4C).

To confirm that CD2-0 and CD2-1 contained the PAMP epitope site, we next investigated whether CD2-0 or CD2-1 also induced other PTI responses in rice, e.g., the induction of several immune-related genes and callose deposition. Protoplasts isolated from cultured rice cells were transformed with an OsWRKY70 promoter-fused luciferase gene, and the transformed protoplasts were treated with $500 \mathrm{nM}$ of native N1141 flagellin, flg22, or CD2-0, which includes the CD2-1 epitope. High levels of luciferase activity were observed $5 \mathrm{~h}$ posttreatment with the native N1141 flagellin and CD2-0, whereas no activation was observed in protoplasts treated with either flg22 or water-alone (Fig. 5A). Next, we examined callose deposition after treatment with recombinant N1141 flagellin, ND0-2, or CD2-1. When cultured rice cells were treated with $200 \mathrm{nM}$ of recombinant N1141 flagellin, ND0-2, or CD2-1, clear callose deposition was observed in N1141 flagellin-treated and CD2-1-treated cells (Fig. 5B and C). In contrast, treatment with ND0-2 did not significantly induce noticeable callose deposition (Fig. 5B and C). These results demonstrated that rice cells have a sensitive perception system specifically recognizing the C-terminal domain of the N1141 flagellin and that the recognition of CD2-1 mainly contributes to the PTI responses induced by the N1141 flagellin.

\section{Global identification of genes regulated} downstream of CD2-0 recognition.

To obtain an overview of the role of CD2-1 in rice PTI responses, we generated transcriptome profiles (Agilent Technologies $44 \mathrm{~K}$ rice DNA oligo microarray) from cultured rice cells exposed to CD2-0, which includes the CD2-1 epitope. Cultured rice cells were treated with CD2-0 for $0,1,3$, or $6 \mathrm{~h}$, and mRNA from the treated cells was used for microarray analysis. After quantitation of signal intensities and normalization, we identified 6,982 genes that were up- or down-regulated following CD2-0 treatment, using a cutoff of a twofold difference in transcript levels between treated and nontreated cells (Fig. 6A). To gain insight into the mechanisms of immunity induced by CD2-0 treatment, we performed hierarchical cluster

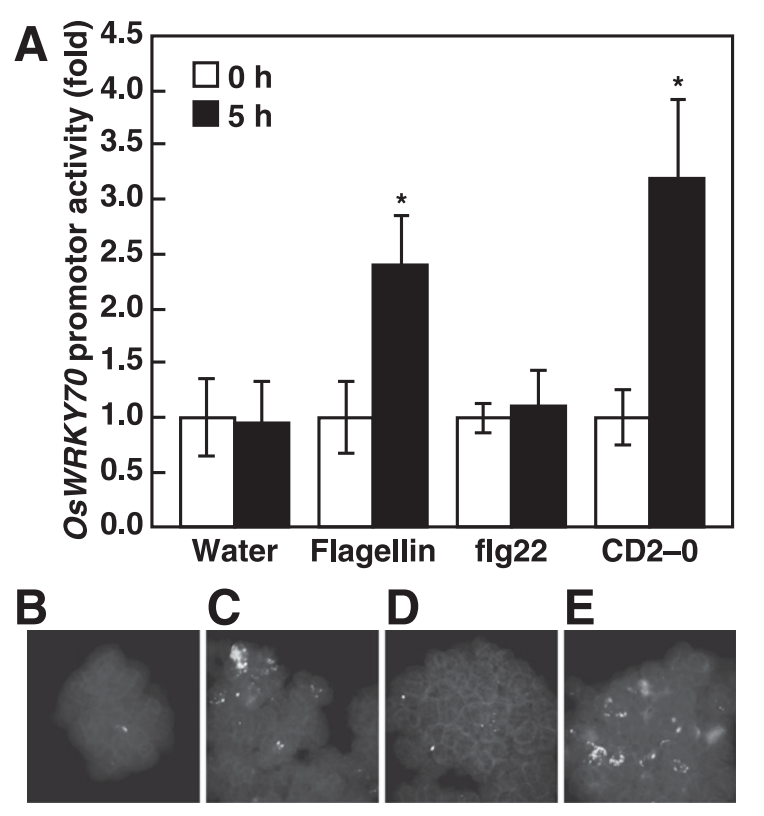

$\mathbf{F}$

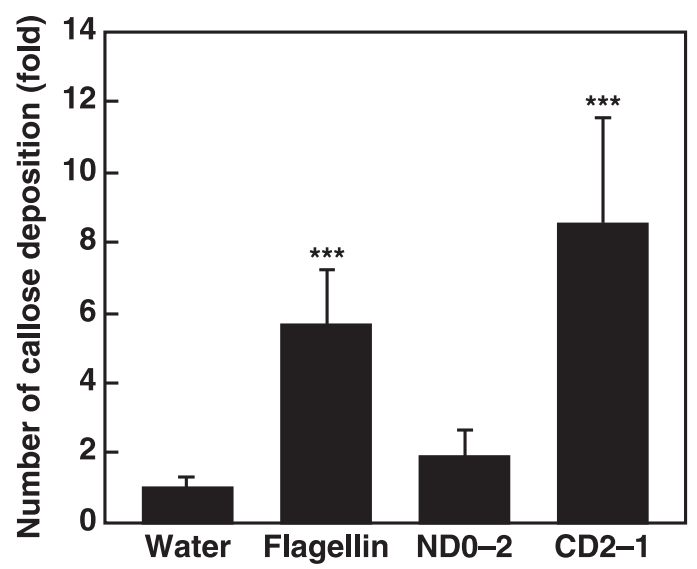

Fig. 5. Responses induced by CD2-1 or CD2-0 in cultured rice cells. A, OsWRKY70 promoter activity in rice protoplasts posttreatment with water, $500 \mathrm{nM}$ native N1141 flagellin, flg22, or CD2-0. Error bars indicate the standard deviation of three experiments. Asterisks indicate mean values that differ significantly from nontreated cells $(0 \mathrm{~h} ; t$ test, $P<0.05)$. B, Callose deposition in cultured rice cells $16 \mathrm{~h}$ posttreatment with water, $\mathbf{C}$, recombinant N1141 flagellin, D, ND0-2, or E, CD2-1. F, Average number of callose deposits per $1-\mathrm{mm}^{2}$ microscopic field. Bars indicate the standard deviation of nine experiments. Asterisks indicate a significant increase in the number of callose deposits observed in cells treated with flagellin and CD2-1 ( $t$ test, $P<0.01)$.

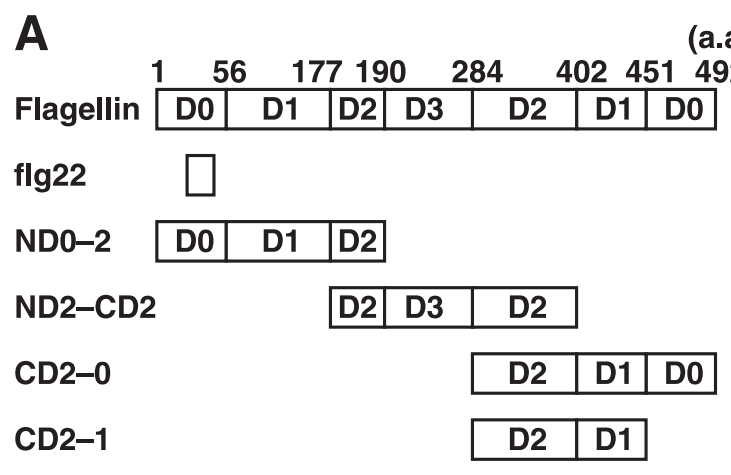

(a.a.)

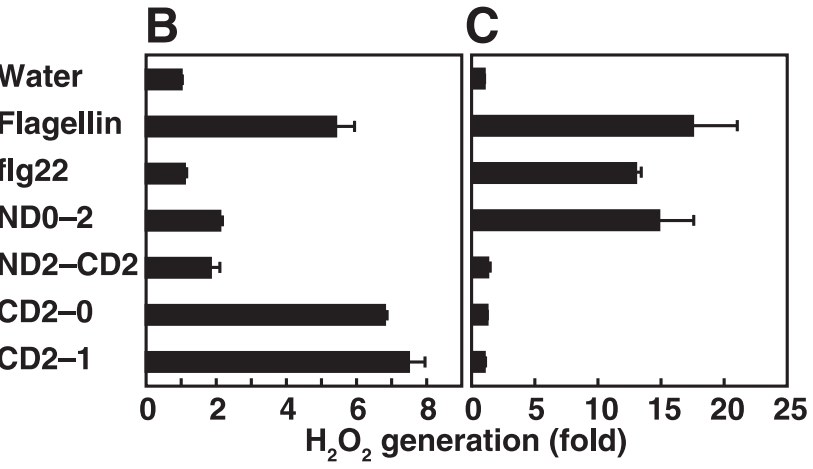

Fig. 4. $\mathrm{H}_{2} \mathrm{O}_{2}$ generation induced by recombinant N1141 flagellin or flagellin fragments in rice and Arabidopsis. A, Structure of N1141 flagellin and its fragments. The flagellin fragment names were derived from flagellin domain names. $\mathbf{B}, \mathrm{H}_{2} \mathrm{O}_{2}$ generation in cultured rice cells and $\mathbf{C}$, Arabidopsis suspension cells treated with $300 \mathrm{nM}$ of each flagellin fragment, assayed $1 \mathrm{~h}$ posttreatment. The $x$ axis represents fold change in $\mathrm{H}_{2} \mathrm{O}_{2}$ in treated relative to mock-treated cell cultures. Error bars indicate the standard deviation of three experiments. 
analysis of these 6,982 genes, which could be classified into six clusters (A to F). Clusters A, B, and C contained genes that were upregulated after CD2-0 treatment (4,093 genes in total), whereas clusters D, E, and F contained genes that were downregulated after the treatment $(2,889$ genes in total). Among the upregulated gene clusters, gene cluster A contained 1,289 genes whose expression was strongly increased by CD2-0 treatment. This cluster contained genes encoding receptor protein kinases and the WRKY transcription factor 70 and pathogenicity-related proteins such as PR-1a. Gene cluster B contained 892 genes whose expression gradually increased. This cluster contained genes encoding plant immune-related proteins and phytoalexin biosynthesis enzymes such as phenylalanine ammonia-lyase, probenazole-inducible protein PBZ1, and thaumatin. Cluster $\mathrm{C}$ included 1,912 genes with an early induction pattern and contained genes encoding transcription factors and signal transduction factors such as RINGtype domain containing protein, bHLH116 transcription factor, zinc finger transcription factor, mitogen-activated protein kinase (MAPK) 8 and calcium-dependent protein kinase 9 (Fig. 6B). However, ETI-related genes, such as $O s N A C 4$, were not included in the upregulated gene clusters, suggesting that CD2-0 induced PTI responses rather than the ETI response. By contrast, clusters D,
E, and $\mathrm{F}$ included 2,889 genes whose expression decreased after CD2-0 treatment and contained genes encoding photosynthesisrelated proteins such as PsbY, metabolism-related proteins such as phosphoenolpyruvate kinase, and growth-related proteins such as cell division control protein $48 \mathrm{a}$.

Induction of PTI responses with distinct

flagellin epitopes in rice and Arabidopsis.

To determine the downstream signaling event following the CD2-0 recognition, MAPK activation by CD2-0 was investigated. It has reported that MAPK3, MAPK4, and MAPK6 were activated after flg22 treatment in Arabidopsis (Asai et al. 2002; Ichimura et al. 2006; Qiu et al. 2008). Arabidopsis suspension cells were treated with either flg22 or CD2-0, and the activation of MAPK was detected by using an antip44/42-ERK antibody. Consistent with previous observations, the activation of MAPK3, MAPK4, and MAPK6 was noted after treatment with either flg22 or native flagellin but not after treatment with CD2-0 (Fig. 7A). By contrast, the three MAPK were clearly activated after CD2-0 but not flg22 treatment of cultured rice cells (Fig. 7B).

Next, we analyzed callose deposition in suspension cells of Arabidopsis. When the cells were treated with $200 \mathrm{nM}$ of
A

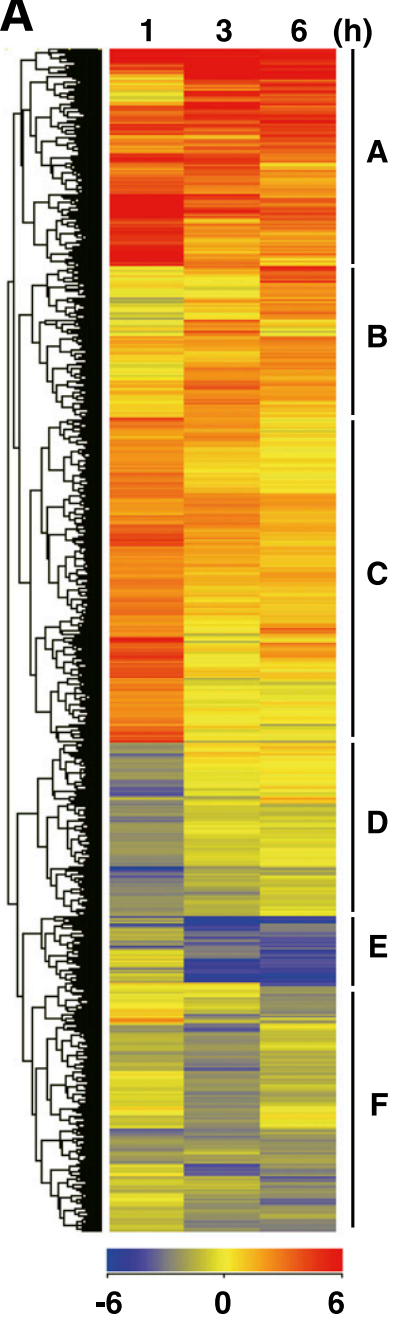

B

\begin{tabular}{cl}
\hline Accession No. & \multicolumn{1}{c}{ Gene identification } \\
\hline $\begin{array}{cl}\text { Cluster A } \\
\text { Os02g0710500 }\end{array}$ & Receptor protein kinase \\
Os05g0474800 & WRKY transcription factor 70 \\
Os07g0127500 & PR-1a \\
Cluster B & \\
Os02g0626100 & Phenylalanine ammonia-lyase \\
Os12g0555500 & Probenazole-inducible protein PBZ1 \\
Os12g0569300 & Thaumatin \\
Cluster C & \\
Os01g0159300 & RING-type domain containing protein \\
Os01g0246700 & WRKY transcription factor 1 \\
Os01g0665200 & Mitogen-activated protein kinase 8 \\
Os01g0705700 & bHLH116 transcription factor \\
Os03g0285800 & MAP kinase \\
Os03g0688300 & Calucium-dependent protein kinase 9 \\
Os03g0764100 & Zinc finger transcription factor ZF1 \\
Os04g0679200 & Receptor-like serine/threonine kinase \\
Os05g0343400 & WRKY transcription factor 53 \\
Os06g0726200 & Endochitinase \\
Cluster D & \\
Os08g0119800 & Photosystem II protein PsbY \\
Os09g0529900 & Pyruvate/Phosphoenolpyruvate kinase \\
Cluster E & \\
Os03g0343900 & Photosystem Il protein PsbX \\
Cluster F & \\
Os07g0635500 & Cytochrome P450 \\
Os03g0151800 & Cell division control protein 48a \\
\hline &
\end{tabular}

Fig. 6. Genome-wide expression profiling. A, Hierarchical cluster analysis of transcripts responsive to CD2-0. Each column represents the fold change in transcript levels from CD2-0-treated cultured rice cells at the indicated times, relative to the transcript levels in mock-treated cultured rice cells. The vertical dimension represents 6,982 genes that exhibit CD2-0-triggered changes in transcript levels (cutoff: $\mid \log _{2}[$ fold change $] \geq 2$ ). B, List of CD2-0-inducible genes. Genes that were changed in expression level by CD2-0 treatment in cultured rice cells were divided into six clusters. Cluster A contains genes that were strongly upregulated, cluster B contains genes whose levels gradually increased through $6 \mathrm{~h}$ posttreatment, cluster $\mathrm{C}$ contains genes whose levels declined through $6 \mathrm{~h}$ posttreatment, cluster D contains genes that transiently downregulated at $1 \mathrm{~h}$ posttreatment, cluster E contains genes that were strongly downregulated, and cluster $\mathrm{F}$ contains genes whose levels gradually decreased through $6 \mathrm{~h}$ posttreatment. 
recombinant N1141 flagellin, ND0-2, or CD2-1, clear callose deposition was observed in N1141 flagellin- and ND0-2-treated cells but not in CD2-1-treated cells (Fig. 7C, D, E, F, and G). Taken together, these results indicated that, although CD2-1 was recognized with a novel receptor unlike OsFLS2, the downstream signaling event following the CD2-1 recognition was in common with that in flg22-treated Arabidopsis.

\section{Induction of resistance to pathogenic bacteria.}

To clarify whether the PTI responses induced by CD2-0 contribute to resistance against plant pathogenic bacteria, the A. avenae avirulent N1141 strain was coinjected into rice leaves with CD2-0. The bacterial numbers of the N1141 strain increased slightly through 3 days postinoculation. When the N1141 strain was coinjected with CD2-0, a statistically significant 10-fold reduction in N1141 growth was observed 3 days postinoculation (Fig. 8A). By contrast, the bacterial number of A. avenae virulent K1 strain increased drastically through 3 days postinoculation. The same growth of $A$. avenae virulent $\mathrm{K} 1$ strains were observed

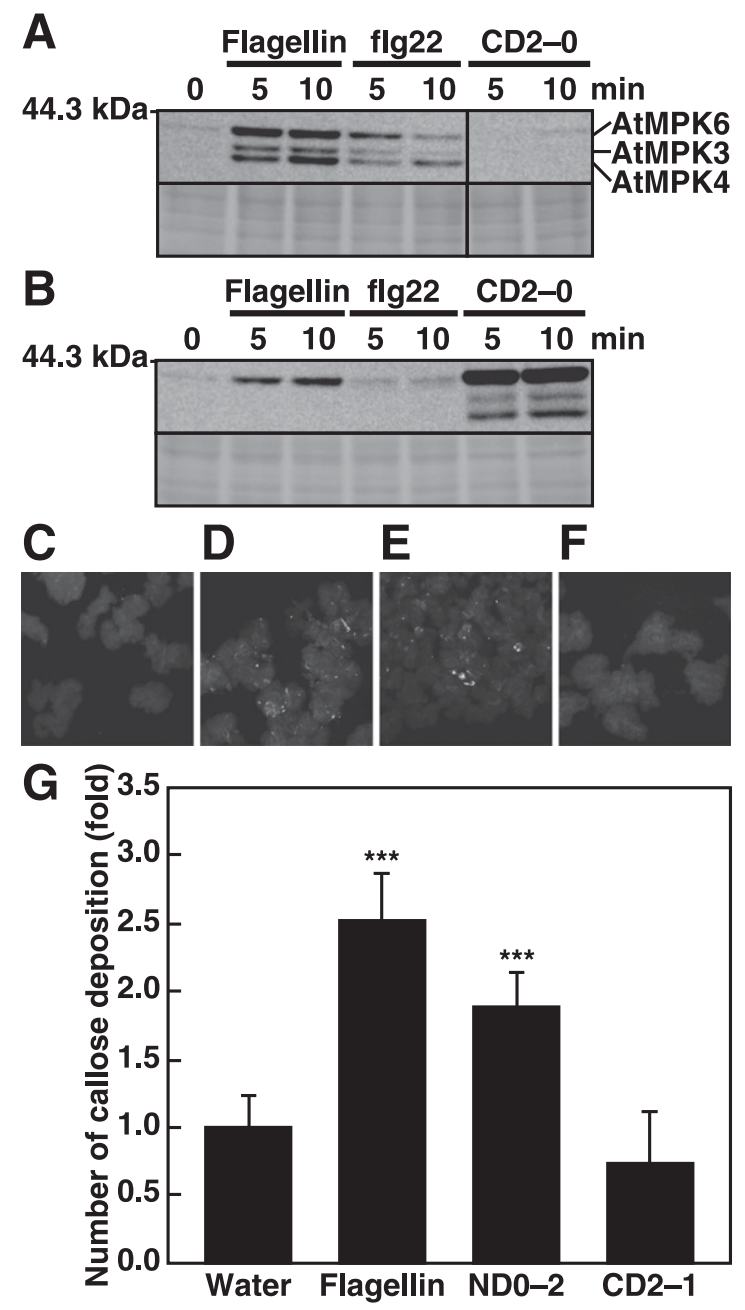

Fig. 7. Induction of several responses by flagellin fragments in rice and Arabidopsis. Phosphorylation in A, Arabidopsis suspension cells and B, cultured rice cells treated with $1 \mu \mathrm{M}$ native N1141 flagellin, flg22, or CD2-0. Callose deposition in C, Arabidopsis suspension cells $16 \mathrm{~h}$ posttreatment with water, D, $200 \mathrm{nM}$ recombinant N1141 flagellin, E, ND0-2, and F, CD2-1. G, Average number of callose deposits per $1-\mathrm{mm}^{2}$ microscopic field. Bars indicate the standard deviation of nine experiments. Asterisks indicate a significant increase $(t$ test, $P<0.01)$ in the number of callose deposits in cells treated with flagellin and ND0-2. in the CD2-0-coinjected rice and the water-coinjected rice through 3 days postinoculation (Fig. 8A). Interestingly, a statistically significant reduction in $\mathrm{K} 1$ growth was observed 10 days postinoculation when K1 strain was coinjected with CD2-0 (Fig. 8B). Importantly, no direct effect of CD2-0 on bacterial growth was detected when the A. avenae N1141 strain was added to Luria Bertani (LB) medium supplemented with $10 \mu \mathrm{M}$ CD2-0, indicating that the peptide was not directly toxic (data not shown). Taken together, the data indicated that inoculation of CD2-0 into rice leaves conferred resistance to plant pathogenic bacteria.

\section{DISCUSSION}

The PAMP-active epitope of flagellin in Arabidopsis, tomato, potato, and tobacco is flg22, localized close to the protein's N-terminus (Felix et al. 1999). To understand the flagellin perception system in rice, we attempted to define the PAMPactive epitope in that organism. Surprisingly, the PAMP-active epitope in rice was located within flagellin's C-terminal D2 and D1 domains. Recombinant CD2-1 induced several PTI responses, including $\mathrm{H}_{2} \mathrm{O}_{2}$ generation, callose deposition, and induction of PTI-related genes, whereas recombinant ND0-2 (N-terminal D0, D1, and D2 domains, containing the flg22 region) and ND2CD2 (N-terminal D2, D3, and C-terminal D2 domains) did not trigger remarkable PTI responses in rice. Taken together, we concluded that the PTI-active epitope of N1141 flagellin in rice resides in the CD2-1 region.

$\mathrm{X}$-ray analysis of available flagellin crystalline complexes show four domains-D0 to D3-labeled from the center of the filament axis outwards in the radial direction. The D0 and D1 domains are core regions that are responsible for filament assembly and polymorphism. The middle domain, D2, is related to the stability of the filament shape. The D3 domain is the central domain of adjacent subunits in a filament that is not connected to each other (Samatey et al. 2001; Yonekura et al. 2003). CD2-1, which contains the active epitope, is composed of the C-terminal D1 and D2 domains. Computer-assisted three-dimensional modeling of N1141 flagellin predicts that the CD2-1 region is located inside in flagellar filament (Supplementary Fig. S1) (Samatey et al. 2001; Yonekura et al. 2003). In addition, the $\mathrm{C}$-terminal region of CD2-1 forms a long, rigid alpha-helical structure, which contributes to flagella filament assembly. We previously reported that rice immune responses are induced by flagellin from the rice avirulent N1141 strain but not by flagellin from the rice virulent $\mathrm{K} 1$ strain. Furthermore, the flagellins of the N1141 and K1 strains are composed of 492 amino acids, with only 14 residues differing between these flagellins (Hirai et al. 2011). Among these different amino acids, eight amino residues were found within the CD2-1. However, the different amino acid residues within CD2-1 were not included in the epitope site because recombinant K1 and N1141 flagellins equally induced PTI responses. Using site-directed mutagenesis, we also showed that glycans were attached to four amino acid residues $\left({ }^{178} \mathrm{Ser},{ }^{183} \mathrm{Ser},{ }^{212} \mathrm{Ser}\right.$, and $\left.{ }^{351} \mathrm{Thr}\right)$ in $\mathrm{K} 1$ flagellin. Among mutant K1 flagellins in which each glycanattached amino acid residue was changed to alanine, ${ }^{178} \mathrm{Ser} / \mathrm{Ala}$ and ${ }^{183}$ Ser/Ala K1 flagellin induced a strong immune response in cultured rice cells, indicating that the glycans at ${ }^{178}$ Ser and ${ }^{183} \mathrm{Ser}$ in $\mathrm{K} 1$ flagellin prevent epitope recognition in rice. Interestingly, ${ }^{178} \mathrm{Ser}$ and ${ }^{183} \mathrm{Ser}$ in flagellin existed within the N-terminal D2 domain but not CD2-1 (Hirai et al. 2011). Further three-dimensional structure analysis will be necessary to clarify whether these glycans three-dimensionally mask the epitope site within CD2-1.

We attempted to identify the exact epitope sites within CD2-1. Accordingly, we produced ten fragments of CD2-1 as GST fusion proteins in E. coli and removed the GST portion of each fusion protein using Prescission protease. Of the resulting 
peptides, CD2-1 $\triangle \mathrm{N} 90$, made by truncating the $90 \mathrm{~N}$-terminal amino acids from CD2-1, and CD2-1 $\triangle \mathrm{C} 30$, made by truncating the $30 \mathrm{C}$-terminal amino acids from CD2-1, were competent to induce PTI in rice (Supplementary Fig. S2). By contrast, CD2$1 \Delta \mathrm{N} 109$, made by truncating the $109 \mathrm{~N}$-terminal amino acids from CD2-1, and CD2-1 $\triangle \mathrm{C} 40$, made by truncating the 40 C-terminal amino acids from CD2-1, did not function as PAMP. Because CD2-1 $\triangle \mathrm{N} 80 \mathrm{C} 30$, which will contain the expected epitope, was not competent to induce PTI in rice, deletion of these parts could conceivably lead to instability of the conformation and results in the inhibition of the perception of the epitope. Indeed, the activity of CD2-1 $\Delta \mathrm{C} 30$ was easily lost, e.g., by freeze-thaw or addition of organic solvent. The detailed conformation study of these peptides will be necessary to clarify a reason for the instability of the PTI-induction activity.

The $\mathrm{N}$ - and C-terminal D0, D1 domains are highly conserved, while D3 is highly variable in both size and sequence (Wilson and Beveridge 1993). The conserved terminal regions interact to form the internal walls of the hollow filament; in this region, fidelity to the correct structure is required for proper assembly of the flagella filament (Malapaka et al. 2007). Strongly conserved molecular domains often function as PAMPs. For example, the LPS found in the outer membranes of gram-negative bacteria also induce PTI responses in plants, and the main PAMP feature recognized from LPS is the widely conserved lipid A (Silipo et al. 2005). Moreover, a synthetic 18-amino acid peptide based on the N-terminal conserved region of E. coli EF-Tu, elf18, is sufficient for recognition by Arabidopsis and other members of the Brassicaceae family (Kunze et al. 2004). Our results fit this theme, whereby the conserved flagellin D1 domain, which is indispensable for microbial fitness, acts as a PAMP and induces PTI responses in rice.

Recently, we reported that two distinct EF-Tu epitopes induced immune responses in rice and Arabidopsis. The elf 18 (first N-terminus 18 amino acids of EF-Tu) was fully active to induce PTI responses in Arabidopsis but not in rice. By contrast, EFa50 (comprising Lys176 to Gly225 of EF-Tu) was fully active as a PAMP in rice (Furukawa et al. 2014). The existence of plural epitope sites has also been reported for other PAMPs or MAMPs. A second flagellin epitope, termed flgII-28, is sufficient to trigger immunity in tomato. The flgII-28 epitope was identified on the basis of two nonsynonymous mutations in almost identical strains of the bacterial speck disease pathogen Pseudomonas syringe pv. tomato, which suggested selection for evasion of flgII-28 perception by tomato (Cai et al. 2011). Responsiveness to flgII-28 has been reported in solanaceous species but not Arabidopsis (Clarke et al. 2013). Although the flgII-28 peptide does not trigger any immune response in Arabidopsis, mutations in both flg22 and flgII-28 have FLS2dependent effects on virulence. However, the expression of a tomato allele of FLS2 does not confer to Nicotiana benthamiana the ability to detect flgII-28, and tomato plants silenced for FLS2 are not altered in flgII-28 recognition. Therefore, allelic variation of flg22 and flgII-28 in flagellin is an effective pathogen virulence strategy (Clarke et al. 2013). In rice case, two flagellin perception systems, flg22 perception system and CD2-1 perception system, were potentially existed in rice. It seems likely that allelic variation of flg22 and CD2-1 is a result of rice defense strategy rather than pathogen virulence strategy. A detailed study about the recognition system of CD2-1 in rice will be necessary to clarify a reason for the acquisition of the new perception system.

Our results showed that flg22 induces very weak PTI responses in rice but that the $\mathrm{C}$-terminal D1 and D2 domains appeared to be required for full PAMP activity in rice. These findings suggest that OsFLS2 functioned as a receptor of flg22 in rice and a receptor other than OsFLS2 mainly contributed to the flagellin perception in rice. In fact, we demonstrated that OsFLS2 is not involved in the perception of CD2-1, which is the main epitope of flagellin in rice. The low contribution of OsFLS2 in the flagellin perception may depend on the expression level of the protein in rice cells.

The immune recognition systems that detect flagellin in both rice and Arabidopsis may have arisen independently from each other, possibly as the result of convergent evolution. Widely conserved features of abundant molecules generally function as immune inducers, such as PAMPs or MAMPs. Various plant
A

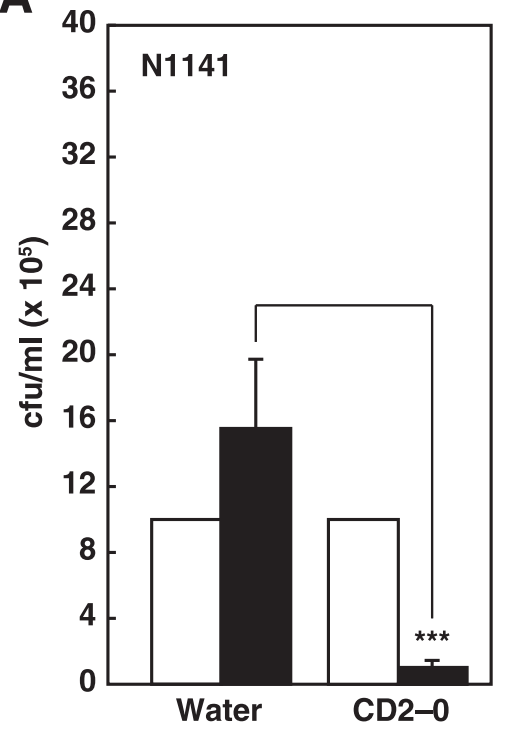

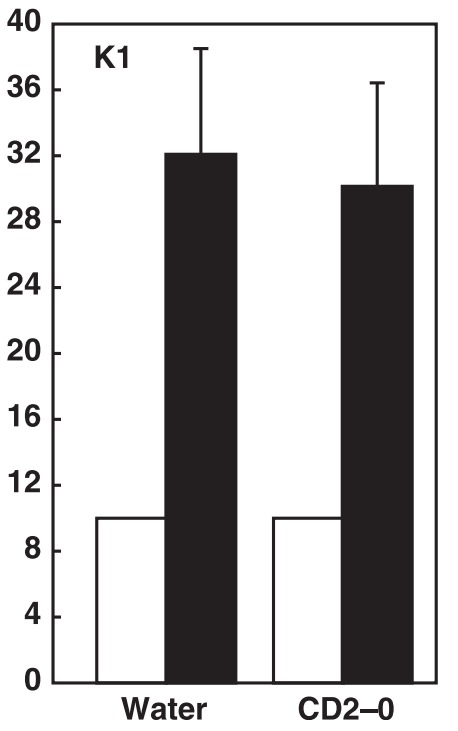

B

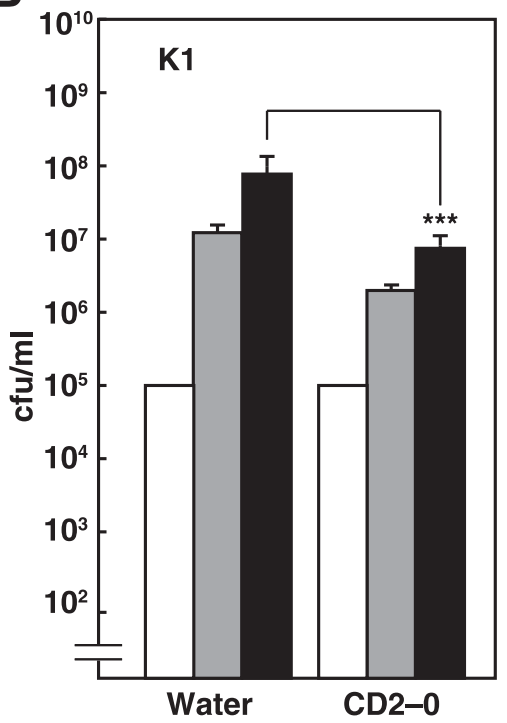

Fig. 8. Effect of CD2-0 on bacterial growth in the short and long term. A, Four-week-old wild-type Nipponbare rice plants were inoculated with Acidovorax avenae avirulent N1141 (left panel) or virulent K1 (right panel) strains at $1 \times 10^{6} \mathrm{CFU}$ with or without $20 \mu \mathrm{M}$ CD2-0, and the bacterial populations in the leaf were determined at 0 (open column) and 3 days (solid column) postinoculation. B, Four-week-old wild-type Nipponbare rice plants were inoculated with the A. avenae $\mathrm{K} 1$ strain at $1 \times 10^{6} \mathrm{CFU}$ with or without $20 \mu \mathrm{M} \mathrm{CD} 2-0$, and the bacterial population in the leaf was determined a 0 (open column), 7 (gray column), and 10 days (solid column) postinoculation. The $y$ axis represents CFU per whole plant. Error bars indicate the standard deviation of three experiments. Asterisks indicate mean values significantly different from treatment with water $(t$ test, $P<0.01)$. 
species could acquire the ability to recognize different parts of those abundant molecules. For example, the PTI-inducer $\beta$-glucan has several specific PAMP recognition sites among plant species. Hepta- $\beta$-glucoside derived from the cell wall of Phytophthora spp., which elicit phytoalexin production in soybean, does not trigger immune responses in rice or tobacco (Fliegmann et al. 2004). Conversely, tetraglucosyl glucitol, a $\beta$-glucan that is structurally different from hepta- $\beta$-glucoside and is derived from the cell wall of the fungus Pyricularia oryzae, induces plant defenses in rice but not in soybean (Yamaguchi et al. 2000).

To clarify the mechanism of CD2-1 recognition in rice, molecules involved in CD2-1 perception should be identified. Previously known flagellin receptors, TLR5 (Hayashi et al. 2001) and FLS2, have extracellular LRR domains, so it is unambiguous that, during evolution, the same biochemical module (LRR) was selected for flagellin recognition in animal and plant lineages. Thus, it is reasonable to expect that the rice flagellin receptor also contains an extracellular LRR domain. The LRR-RLK in the rice genome were estimated to contain 384 members, which is 1.6fold the size of the 240 LRR-RLK in Arabidopsis (Shiu et al. 2004). Interestingly, LRR-XII, one of the LRR-RLK subfamilies containing FLS2 and the resistance gene Xa21 (Song et al. 1995), is differentially expanded in rice ( 117 members) and Arabidopsis (six members). This differential expansion of an immune response-related gene family in rice might be the result of artificial selection for disease-resistant varieties during rice domestication. Thus, the perception of pathogen-derived molecules, including flagellin, in rice is thought to be more divergent and complicated than in Arabidopsis.

\section{MATERIALS AND METHODS}

\section{Plants and bacteria.}

Suspension cultures of rice cells, line Oc, were grown at $30^{\circ} \mathrm{C}$ under light irradiation (Baba et al. 1986). The cells were diluted in fresh medium every week, and all experiments were performed 4 days after transfer. Suspension cultures of Arabidopsis thaliana cells, line $\mathrm{T} 87$, were grown at $23^{\circ} \mathrm{C}$ under a $16-\mathrm{h}$ light and 8-h dark photoperiod. The cells were diluted in fresh medium every week, and all experiments were performed 7 days after transfer. Acidovorax avenae N1141 (MAFF 301141) was used as previously described (Che et al. 2000; Kadota et al. 1996).

\section{Purification of flagellin from A. avenae $\mathrm{N1141}$ strain.}

Flagellin was purified as previously described (Che et al. 2000), with the following modifications. The $A$. avenae N1141 strain was grown for 1.5 days in $\mathrm{LB}$ medium at $30^{\circ} \mathrm{C}$ on a rotary shaker. The cells were harvested by centrifugation at $6,000 \times g$ for $20 \mathrm{~min}$ at $4^{\circ} \mathrm{C}$. The pellets were washed with TBS buffer $(25 \mathrm{mM}$ Tris- $\mathrm{HCl}$, $\mathrm{pH} 7.5,137 \mathrm{mM} \mathrm{NaCl}$, and $2.68 \mathrm{mM} \mathrm{KCl}$ ), were collected by centrifugation, and were then resuspended in $20 \mathrm{ml}$ of TBS buffer. Flagella were removed from the cells by shearing for $3 \mathrm{~min}$ in a homogenizer (Ultra F Homogenizer HF-93-F; TAITEC). Intact cells and cellular debris were removed, using a two-step centrifugation procedure at $6,000 \times g$ for $30 \mathrm{~min}$ and $16,000 \times g$ for $60 \mathrm{~min}$ at $4^{\circ} \mathrm{C}$. The flagella were collected by ultracentrifugation at $200,000 \times g$ for $60 \mathrm{~min}$ at $4^{\circ} \mathrm{C}$. The pellets were resuspended in distilled water and were centrifuged at $20,000 \times g$ for $20 \mathrm{~min}$ at $4^{\circ} \mathrm{C}$. After the supernatants were removed, the flagellin preparations were stored at $-80^{\circ} \mathrm{C}$.

\section{Plasmid constructs.}

Construction of pOsWRKY70-luc reporter plasmid and pET28b-Fla expression plasmid has been described previously (Hirai et al. 2011; Takai et al. 2007).
To construct GST-tagged ND0-2, ND2-CD2, and CD2-0, $N D 0-2, N D 2-C D 2$, and $C D 2-0$ regions of $A$. avenae N1141 flagellin were amplified using specific primer sets $(N D O-2$ : forward, 5'-GGATCCATGGCATCCACCATCAACACC-3', where GGATCC is the BamHI site and reverse, 5'-GGATCCGCC GAGCCGGCCGTG-3', where GGATCC is the BamHI site; ND2$C D$ 2: forward, 5'-GAATTCGGCCACCGGCGCGGCCAC-3', where GAATTC is the EcoRI site and reverse, 5'-GAATTCTCCGTC CACGGTGGACACGTCGATG-3', where GAATTC is the EcoRI site; and CD2-0: forward, 5'-GAATTCCGACGTGTCCTCGCA GACC-3', where GAATTC is the EcoRI site and reverse, 5'-GAATTCACGCAGCAGGGACAGCAC-3', where GAATTC is the EcoRI site) from the A. avenae N1141 genome. PCR products were ligated and cloned into Zero-Blunt vector (Invitrogen). The resulting plasmids $p C R$-Blunt-NDO-2, $p C R$-BluntND2-CD2, or $p C R$-Blunt-CD2-O were digested with BamHI or $E c o$ RI and were then cloned into $p G E X 6 P-3$ vector (GE Healthcare) to generate the expression plasmids $p G E X 6 P-3-N D O-2$, $p G E X 6 P-3-N D 2-C D 2$, or $p G E X 6 P-3-C D 2-0$. To construct GSTtagged CD2-1, $p G E X 6 P-3-C D 2-1$ were produced using a specific primer set (forward, 5'-GAATTCCCGGGTCGACTCGAGCGGC-3' and reverse, 5'-GCGGCTGCGCGAGGCGGACATGTTC-3'), pGEX6P-3-CD2-0, and the KOD-plus mutagenesis kit (Takara Bio, Inc.), according to the manufacturer's instructions.

To generate double stranded RNA expression vector, the OsFLS2 mRNA-specific region (325 bp) was amplified using specific primers (forward, 5'-CACCTGGACCCCCGCATGAAGGTC-3', where CACC is the TOPO cloning sequence and reverse, 5'CCTCATCAATGGAGAAAGTTCGCAATGC-3') from OsFLS2 cDNA. PCR product was ligated and cloned into pENTR D-TOPO as an entry vector (Invitrogen), according to the manufacturer's instructions. The entry vector was cloned into $p A N D A$ (Kaneda et al. 2009) as a double stranded RNA expression vector by LR clonase reaction (LR clonase II enzyme mix; Invitrogen), according to the manufacturer's instructions. The resulting plasmid was termed $p A N D A-O s F L S 2$.

\section{Preparation of recombinant proteins.}

For preparation of the His-tagged flagellin, recombinant proteins were expressed by isopropyl- $\beta$-D(-)-thiogalactopyranoside (IPTG) treatment in BL21 (DE3) carrying pET28b-Fla in LB medium at $15^{\circ} \mathrm{C}$ for $18 \mathrm{~h}$. The $E$. coli were harvested by centrifugation at $7,000 \times g$ for $15 \mathrm{~min}$ at $4^{\circ} \mathrm{C}$. The pellets were washed with phosphate buffered saline (PBS) (pH 7.3) and were resuspended in $30 \mathrm{ml}$ of $\mathrm{PBS}$ ( $\mathrm{pH} 7.3$ ). The resuspended E. coli were crushed by sonication for $5 \mathrm{~min}$ at $4{ }^{\circ} \mathrm{C}$ and were then centrifuged at $15,300 \times g$ to remove intact cells and cellular debris. The supernatant was applied to Ni-NTA agarose (Qiagen) according to the manufacturer's instructions. The eluted proteins were ultrafiltered by Amicon Ultra (Merck Millipore) for enrichment and desalting.

To prepare the GST-tagged ND0-2, ND2-CD2, CD2-0, and CD2-1, these recombinant proteins were expressed by IPTG treatment in BL21 (DE3) carrying $p$ GEX6P-3-ND0-2, pGEX6P-3-ND2-CD2, $p G E X 6 P-3-C D 2-0$, or $p G E X 6 P-3-C D 2-1$ in $\mathrm{LB}$ medium at $15^{\circ} \mathrm{C}$ for $18 \mathrm{~h}$. The $E$. coli were harvested by centrifugation at $7,000 \times g$ for $15 \mathrm{~min}$ at $4^{\circ} \mathrm{C}$. The pellets were washed with PBS ( $\mathrm{pH} 7.3$ ) and were resuspended in $30 \mathrm{ml}$ of PBS (pH 7.3). The resuspended E. coli were crushed by sonication for $5 \mathrm{~min}$ at $4{ }^{\circ} \mathrm{C}$ and were then centrifuged at $15,300 \times g$ to remove intact cells and cellular debris. The supernatant was applied to GSTrap FF (GE Healthcare) and were eluted by PreScission Protease (GE Healthcare), according to the manufacturer's instructions. The eluted proteins were ultrafiltered by Amicon Ultra (Merck Millipore) for enrichment and desalting. The concentrations of proteins were determined using the Quick Start protein assay (Bio-Rad) with bovine serum albumin (BSA) as a standard. 


\section{Oligopeptides.}

The flg22 (QRLSTGSRINSAKDDAAGLQIA) and flg22avenae (QRLSSGLRINSAKDDAAGLAIS) oligopeptides were synthesized at Eurofins Genomics K.K. or Sigma-Aldrich Japan.

\section{$\mathrm{H}_{2} \mathrm{O}_{2}$ detection and quantification.}

$\mathrm{H}_{2} \mathrm{O}_{2}$ produced in the medium of cultured cells was monitored based on chemiluminescence due to the ferricyanidecatalyzed oxidation of luminol (5-amino-2,3 dihydro-1,4phthalazinedione) as described by Schwacke and Hager (1992). Ten milligrams of cultured rice cells or Arabidopsis cells were transferred to $500 \mu \mathrm{l}$ of fresh medium and were preincubated for $2 \mathrm{~h}$ at 30 or $23^{\circ} \mathrm{C}$. Cultured rice cells or Arabidopsis cells were incubated with elicitors $(<50 \mu \mathrm{l})$ at 30 or $23^{\circ} \mathrm{C}$ for the incubated periods after treatment. Following this incubation, $10 \mu \mathrm{l}$ of the medium were harvested, were added to $180 \mu \mathrm{l}$ of $50 \mathrm{mM}$ potassium phosphate buffer (pH7.9) containing $14 \mathrm{mM}$ potassium ferricyanide and $10 \mu \mathrm{l}$ of $1.1 \mathrm{mM}$ luminol and were immediately analyzed for chemiluminescence using a PHELIOS (AB-2350, ATTO).

\section{RNA isolation and real-time qRT-PCR.}

Total RNA was isolated from cultured rice cells using an RNeasy plant mini kit (Qiagen) with DNase digestion, according to the manufacturer's instructions. qRT-PCR was performed on an Opticon2 instrument (Bio-Rad), using a GoTaq One-Step RT-qPCR kit (Promega Corp.) and the following gene-specific primers: OsWRKY70, PBZ1, Cht-1 (Takai et al. 2007), PAL (Hirai et al. 2011), and 25S rRNA (forward 5'-AAGGCCGA AGAGGAGAAAGGT-3', reverse 5'-CGTCCCTTAGGATC GGCTTAC-3'). The mRNA levels were normalized to $25 \mathrm{~S}$ $r R N A$ as an internal control.

\section{Production of OSFLS2 RNAi knockdown line.}

The $p A N D A-O s F L S 2$ vector was introduced into the Agrobacterium tumefaciens EHA105 strain by electroporation. Agrobacterium-mediated transformation of rice cv. Kinmaze was performed as described previously (Toki 1997).

\section{Protoplast isolation and transformation.}

Protoplast isolation and transient transformation using suspension-cultured rice cells were carried out as described previously (Takai et al. 2007). The protoplast concentration was quantified using $\mathrm{s}$ hemocytometer and a light microscope. Transient transformation was performed as previously described (Takai et al. 2007) with several modifications. The protoplasts were resuspended at $2 \times 10^{5}$ cells $/ \mathrm{ml}$ in $\mathrm{MMg}$ solution (0.3 M manitol, $15 \mathrm{mM} \mathrm{MgCl}_{2}$, and $4 \mathrm{mM}$ MES-KOH, pH5.7). The protoplast suspension $\left(0.2 \mathrm{ml}, 4 \times 10^{4}\right.$ cells $)$ was gently mixed with $2.5 \mu \mathrm{g}$ of reporter luciferase plasmid ( $\mathrm{OOsWRKY70-}$ $l u c$ ) and $0.21 \mathrm{ml}$ of PEG solution (0.2 M manitol, $100 \mathrm{mM}$ $\mathrm{CaCl}_{2}$, and $40 \%$ PEG 4000). After incubation for $30 \mathrm{~min}$ at room temperature, the protoplasts were diluted with $0.8 \mathrm{ml}$ of $\mathrm{KMC}$ solution $\left(117 \mathrm{mM} \mathrm{KCl}, 82 \mathrm{mM} \mathrm{MgCl}\right.$, and $\left.85 \mathrm{mM} \mathrm{CaCl}_{2}\right)$ and were centrifuged at $200 \times g$ for $5 \mathrm{~min}$ at room temperature. After the supernatant was removed, the protoplasts were suspended in $100 \mu \mathrm{l}$ of $\mathrm{KMC}$ solution and were incubated in the dark at $30^{\circ} \mathrm{C}$ for $16 \mathrm{~h}$ before assay.

\section{Protoplast transient expression assay.}

Transient expression assay using rice protoplast was performed as described previously (Takai et al. 2007) with the following modifications. The reporter luciferase plasmids-transfected protoplasts were treated elicitors $(500 \mathrm{nM})$ and were incubated in the dark at $30^{\circ} \mathrm{C}$ for $5 \mathrm{~h}$. After the incubation, the protoplasts were lysed in $50 \mu \mathrm{l}$ of lysis buffer (Dual-Luciferase reporter assay system; Promega) and were incubated for $10 \mathrm{~min}$ at room temperature. After incubation, the lysate was mixed with luciferin solution (beetle luciferin; Dual-Luciferase reporter assay system, Promega). Luminescence of protoplast samples was quantified using a PHELIOS (AB-2350; ATTO).

\section{Callose staining.}

Detection of callose deposition was performed as described previously (Furukawa et al. 2014). Cultured rice cells and Arabidopsis cells were treated with $200 \mathrm{nM}$ elicitors and were incubated for $16 \mathrm{~h}$ at 30 or $23^{\circ} \mathrm{C}$.

\section{Microarray analysis.}

Cultured rice cells were incubated with R2S medium containing $300 \mathrm{nM} \mathrm{CD} 2-0$ at $30^{\circ} \mathrm{C}$ for $0,1,3$, and $6 \mathrm{~h}$ after treatment. Total RNA was isolated from cultured rice cells using the RNeasy plant mini kit (Qiagen) with DNase digestion, according to the manufacturer's instructions. Microarray analysis was performed as described previously (Furukawa et al. 2014).

\section{MAPK assay.}

Detection of phosphor-MAPK was performed as described previously (Singh et al. 2012), with the following modifications. Phosphorylation of MAPK were determined in crude protein extracts from cultured rice cells or Arabidopsis cells treated with $1 \mu \mathrm{M}$ elicitors for 5 or $10 \mathrm{~min}$ and were prepared as described previously (Romeis et al. 1999). The protein concentration was determined using the Quick Start protein assay (Bio-Rad) with BSA as a standard. Crude extracts (10 $\mu \mathrm{g}$ total protein per lane) were separated on a $12.5 \%$ sodium dodecyl sulfate gel, and proteins were transferred onto nitrocellulose membrane (GE Healthcare) by semidry electroblotting (Bio-Rad). Phosphorylated MAPK were detected by overnight incubation with anti phospho-p42/44 MPK primary antibodies $(1: 2,000)$ (Cell Signaling Technology), followed by incubation with antirabbit immunoglobulin $\mathrm{G}(\mathrm{H}+\mathrm{L}$ chain)-horseradish peroxidase secondary antibodies (MBL) for $30 \mathrm{~min}$. The signals were visualized using ECL Plus Western blotting detection system (GE Healthcare), following the manufacturer's instructions.

\section{Inoculation experiment.}

Inoculation of rice plants (Oryza sativa L. Nipponbare) with A. avenae and counting of A. avenae (CFU) were performed as described previously (Furukawa et al. 2014).

\section{ACKNOWLEDGMENTS}

We are grateful to H. Morii for excellent technical support. This work was supported, in part, by Technology of Japan and the Program for Promotion of Basic and Applied Research for Innovations in Bio-Oriented Industry and Grant-in-Aid for Scientific Research (B) (25292067) from the Ministry of Education, Culture, Sports, Science.

\section{LITERATURE CITED}

Asai, T., Tena, G., Plotnikova, J., Willmann, M. R., Chiu, W. L., GomezGomez, L., Boller, T., Ausubel, F. M., and Sheen, J. 2002. MAP kinase signalling cascade in Arabidopsis innate immunity. Nature 415:977-983.

Baba, A., Hasezawa, S., and Syono, K. 1986. Cultivation of rice protoplasts and their transformation mediated by Agrobacterium spheroplasts. Plant Cell Physiol. 27:463-472.

Boller, T., and Felix, G. 2009. A renaissance of elicitors: perception of microbe-associated molecular patterns and danger signals by patternrecognition receptors. Annu. Rev. Plant Biol. 60:379-406.

Cai, R., Lewis, J., Yan, S., Liu, H., Clarke, C. R., Campanile, F., Almeida, N. F., Studholme, D. J., Lindeberg, M., Schneider, D., Zaccardelli, M., Setubal, J. C., Morales-Lizcano, N. P., Bernal, A., Coaker, G., Baker, C., Bender, C. L., Leman, S., and Vinatzer, B. A. 2011. The plant pathogen Pseudomonas syringae pv. tomato is genetically monomorphic and 
under strong selection to evade tomato immunity. PLoS Pathog. 7: e1002130.

Che, F. S., Iwano, M., Tanaka, N., Takayama, S., Minami, E., Shibuya, N., Kadota, I., and Isogai, A. 1999. Biochemical and morphological features of rice cell death induced by Pseudomonas avenae. Plant Cell Physiol. 40:1036-1045.

Che, F. S., Nakajima, Y., Tanaka, N., Iwano, M., Yoshida, T., Takayama, S., Kadota, I., and Isogai, A. 2000. Flagellin from an incompatible strain of Pseudomonas avenae induces a resistance response in cultured rice cells. J. Biol. Chem. 275:32347-32356.

Clarke, C. R., Chinchilla, D., Hind, S. R., Taguchi, F., Miki, R., Ichinose, Y., Martin, G. B., Leman, S., Felix, G., and Vinatzer, B. A. 2013. Allelic variation in two distinct Pseudomonas syringae flagellin epitopes modulates the strength of plant immune responses but not bacterial motility. New Phytol. 200:847-860.

Felix, G., Duran, J. D., Volko, S., and Boller, T. 1999. Plants have a sensitive perception system for the most conserved domain of bacterial flagellin. Plant J. 18:265-276.

Fliegmann, J., Mithofer, A., Wanner, G., and Ebel, J. 2004. An ancient enzyme domain hidden in the putative beta-glucan elicitor receptor of soybean may play an active part in the perception of pathogen-associated molecular patterns during broad host resistance. J. Biol. Chem. 279: 1132-1140.

Fujiwara, S., Tanaka, N., Kaneda, T., Takayama, S., Isogai, A., and Che, F. S. 2004. Rice cDNA microarray-based gene expression profiling of the response to flagellin perception in cultured rice cells. Mol. Plant Microbe Interact. 17:986-998.

Furukawa, T., Inagaki, H., Takai, R., Hirai, H., and Che, F. S. 2014. Two distinct EF-Tu epitopes induce immune responses in rice and Arabidopsis. Mol. Plant Microbe Interact. 27:113-124.

Gómez-Gómez, L., and Boller, T. 2000. FLS2: an LRR receptor-like kinase involved in the perception of the bacterial elicitor flagellin in Arabidopsis. Mol. Cell 5:1003-1011.

Hayashi, F., Smith, K. D., Ozinsky, A., Hawn, T. R., Yi, E. C., Goodlett D. R., Eng, J. K., Akira, S., Underhill, D. M., and Aderem, A. 2001. The innate immune response to bacterial flagellin is mediated by toll-like receptor 5. Nature 410:1099-1103.

Hirai, H., Takai, R., Iwano, M., Nakai, M., Kondo, M., Takayama, S., Isogai, A. and Che, F. S. 2011. Glycosylation regulates specific induction of rice immune responses by Acidovorax avenae flagellin. J. Biol. Chem. 286:25519-25530.

Ichimura, K., Casais, C., Peck, S. C., Shinozaki, K., and Shirasu, K. 2006. MEKK1 is required for MPK4 activation and regulates tissue-specific and temperature-dependent cell death in Arabidopsis. J. Biol. Chem. 281:36969-36976.

Iwano, M., Che, F. S., Goto, K., Tanaka, N., Takayama, S., and Isogai, A. 2002. Electron microscopic analysis of the $\mathrm{H}_{2} \mathrm{O}_{2}$ accumulation preceding hypersensitive cell death induced by an incompatible strain of Pseudomonas avenae in cultured rice cells. Mol. Plant Pathol. 3:1-8.

Jones, J. D., and Dangl, J. L. 2006. The plant immune system. Nature 444: 323-329.

Kadota, I., Mizuno, A., and Nishiyama, K. 1996. Detection of a protein specific to the strain of Pseudomonas avenae Manns 1909 pathogenic to rice. Jpn. J. Phytopathol. 62:425-428.

Kaku, H., Nishizawa, Y., Ishii-Minami, N., Akimoto-Tomiyama, C., Dohmae, N., Takio, K., Minami, E., and Shibuya, N. 2006. Plant cells recognize chitin fragments for defense signaling through a plasma membrane receptor. Proc. Natl. Acad. Sci. USA 103:11086-11091.

Kaneda, T., Taga, Y., Takai, R., Iwano, M., Matsui, H., Takayama, S., Isogai, A., and Che, F. S. 2009. The transcription factor OsNAC4 is a key positive regulator of plant hypersensitive cell death. EMBO J. 28:926-936.

Klarzynski, O., Plesse, B., Joubert, J. M., Yvin, J. C., Kopp, M., Kloareg, B., and Fritig, B. 2000. Linear beta-1,3 glucans are elicitors of defense responses in tobacco. Plant Physiol. 124:1027-1038.

Komoriya, K., Shibano, N., Higano, T., Azuma, N., Yamaguchi, S., and Aizawa, S. I. 1999. Flagellar proteins and type III-exported virulence factors are the predominant proteins secreted into the culture media of Salmonella typhimurium. Mol. Microbiol. 34:767-779.

Kunze, G., Zipfel, C., Robatzek, S., Niehaus, K., Boller, T., and Felix, G. 2004. The $\mathrm{N}$ terminus of bacterial elongation factor Tu elicits innate immunity in Arabidopsis plants. Plant Cell 16:3496-3507.

Laquitaine, L., Gomès, E., François, J., Marchive, C., Pascal, S., Hamdi, S., Atanassova, R., Delrot, S., and Coutos-Thévenot, P. 2006. Molecular basis of ergosterol-induced protection of grape against Botrytis cinerea: induction of type I LTP promoter activity, WRKY, and stilbene synthase gene expression. Mol. Plant Microbe Interact. 19:1103-1112.

Luna, E., Pastor, V., Robert, J., Flors, V., Mauch-Mani, B., and Ton, J. 2011 Callose deposition: a multifaceted plant defense response. Mol. Plant Microbe Interact. 24:183-193.
Malapaka, R. R., Adebayo, L. O., and Tripp, B. C. 2007. A deletion variant study of the functional role of the Salmonella flagellin hypervariable domain region in motility. J. Mol. Biol. 365:1102-1116.

Nakashita, H., Yoshioka, K., Takayama, M., Kuga, R., Midoh, N., Usami, R. Horikoshi, K., Yoneyama, K., and Yamaguchi, I. 2001. Characterization of PBZ1, a probenazole-inducible gene, in suspension-cultured rice cells. Biosci. Biotechnol. Biochem. 65:205-208.

Qiu, J. L., Zhou, L., Yun, B. W., Nielsen, H. B., Fiil, B. K., Petersen, K., Mackinlay, J., Loake, G. J., Mundy, J., and Morris, P. C. 2008. Arabidopsis mitogen-activated protein kinase kinases MKK1 and MKK2 have overlapping functions in defense signaling mediated by MEKK1, MPK4, and MKS1. Plant Physiol. 148:212-222.

Romeis, T., Piedras, P., Zhang, S., Klessig, D. F., Hirt, H., and Jones, J. D. 1999. Rapid Avr9- and Cf-9 -dependent activation of MAP kinases in tobacco cell cultures and leaves: convergence of resistance gene, elicitor, wound, and salicylate responses. Plant Cell 11:273-287.

Samakovlis, C., Asling, B., Boman, H. G., Gateff, E., and Hultmark, D. 1992. In vitro induction of cecropin genes-An immune response in a Drosophila blood cell line. Biochem. Biophys. Res. Commun. 188 1169-1175.

Samatey, F. A., Imada, K., Nagashima, S., Vonderviszt, F., Kumasaka, T., Yamamoto, M., and Namba, K. 2001. Structure of the bacterial flagellar protofilament and implications for a switch for supercoiling. Nature 410: 331-337.

Schuster, S. C., and Khan, S. 1994. The bacterial flagellar motor. Annu. Rev. Biophys. Biomol. Struct. 23:509-539.

Schwacke, R., and Hager, A. 1992. Fungal elicitors induce a transient release of active oxygen species from cultured spruce cells that is dependent on $\mathrm{Ca}\left({ }^{2+}\right)$ and protein-kinase activity. Planta 187:136-141.

Shiu, S. H., Karlowski, W. M., Pan, R., Tzeng, Y. H., Mayer, K. F., and Li, W. H. 2004. Comparative analysis of the receptor-like kinase family in Arabidopsis and rice. Plant Cell 16:1220-1234.

Silipo, A., Molinaro, A., Sturiale, L., Dow, J. M., Erbs, G., Lanzetta, R., Newman, M. A., and Parrilli, M. 2005. The elicitation of plant innate immunity by lipooligosaccharide of Xanthomonas campestris. J. Biol Chem. 280:33660-33668.

Singh, P., Kuo, Y. C., Mishra, S., Tsai, C. H., Chien, C. C., Chen, C. W., Desclos-Theveniau, M., Chu, P. W., Schulze, B., Chinchilla, D., Boller, T., and Zimmerli, L. 2012. The lectin receptor kinase-VI.2 is required for priming and positively regulates Arabidopsis pattern-triggered immunity. Plant Cell 24:1256-1270.

Song, W. Y., Wang, G. L., Chen, L. L., Kim, H. S., PiL. Y.Holsten. T., Gardner. J., Wang. B., Zhai. W. X., Zhu. L. H., Fauquet. C., Ronald. P. 1995. A receptor kinase-like protein encoded by the rice disease resistance gene, Xa21. Science 270:1804-1806.

Takai, R., Kaneda, T., Isogai, A., Takayama, S., and Che, F. S. 2007. A new method of defense response analysis using a transient expression system in rice protoplasts. Biosci. Biotechnol. Biochem. 71:590-593.

Takai, R., Isogai, A., Takayama, S., and Che, F. S. 2008. Analysis of flagellin perception mediated by flg22 receptor OsFLS2 in rice. Mol. Plant Microbe Interact. 21:1635-1642.

Tanaka, N., Nakajima, Y., Kaneda, T., Takayama, S., Che, F. S., and Isogai, A. 2001. DNA laddering during hypersensitive cell death in cultured rice cell induced by an incompatible strains of Pseudomonas avenae. Plant Biotechnol. 18:295-299.

Tanaka, N., Che, F. S., Watanabe, N., Fujiwara, S., Takayama, S., and Isogai, A. 2003. Flagellin from an incompatible strain of Acidovorax avenae mediates $\mathrm{H}_{2} \mathrm{O}_{2}$ generation accompanying hypersensitive cell death and expression of $P A L, C h t-1$, and $P B Z 1$, but not of Lox in rice. Mol. Plant Microbe Interact. 16:422-428.

Toki, S. 1997. Rapid and efficient Agrobacterium-mediated transformation in rice. Plant Mol. Biol. Rep. 15:16-21.

Wilson, D. R., and Beveridge, T. J. 1993. Bacterial flagellar filaments and their component flagellins. Can. J. Microbiol. 39:451-472.

Wyant, T. L., Tanner, M. K., and Sztein, M. B. 1999. Potent immunoregulatory effects of Salmonella typhi flagella on antigenic stimulation of human peripheral blood mononuclear cells. Infect. Immun. 67:1338-1346.

Yamaguchi, T., Yamada, A., Hong, N., Ogawa, T., Ishii, T., and Shibuya, N. 2000. Differences in the recognition of glucan elicitor signals between rice and soybean: beta-glucan fragments from the rice blast disease fungus Pyricularia oryzae that elicit phytoalexin biosynthesis in suspension-cultured rice cells. Plant Cell 12:817-826.

Yonekura, K., Maki-Yonekura, S., and Namba, K. 2003. Complete atomic model of the bacterial flagellar filament by electron cryomicroscopy. Nature 424:643-650.

Zhu, Q., Dabi, T., Beeche, A., Yamamoto, R., Lawton, M. A., and Lamb, C. 1995. Cloning and properties of a rice gene encoding phenylalanine ammonia-lyase. Plant Mol. Biol. 29:535-550. 